\title{
CARDIOVASCULAR AUTONOMIC TESTS IN DIABETIC PATIENTS WITH GASTROPARESIS
}

\author{
LEILA M.B.ARAUJO*, ROY FREEMAN**, CHRISTOFERSON BROADBRIDGE**
}

\begin{abstract}
The aim of this report was to study the cardiovascular autonomic tests in the evaluation of diabetic patients with gastroparesis. Forty diabetic subjects were divided into two groups: one group with gastroparesis (GP, $n=20$ ) and another group paired by age and duration of diabetes without any complaint of autonomic neuropathy (DC, $n=20$ ). They were evaluated clinically and submitted to a battery of five cardiovascular autonomic tests. The presence and severity of autonomic neuropathy were defined according to the number of normal cardiovascular tests. Each test had a score: zero ( normal), one (borderline) and two ( abnormal ). The GP group showed a higher abnormal total score in the cardiovaseular autonomic test than the group without any complaint $(6.6 \pm 3.0$ vs $2.7 \pm 1.4, p<0.01)$. These data suggest that diabetic with gastroparesis presents more abnormal cardiovascular autonomic tests than diabetic without autonomic neuropathy and these tests should be included in the evaluation of diabetic patients with gastroparesis.
\end{abstract}

KEY WORDS: gastroparesis, autonomic neuropathy, cardiovascular autonomic test , diabetic neuropathy.

\section{Testes autonômicos cardiovasculares em diabéticos com gastroparesia}

RESUMO - O objetivo deste estudo foi investigar a importância dos testes autonômicos na avaliação de pacientes diabéticos com gastroparesia. Foram estudados 40 diabéticos, divididos em dois grupos: um grupo de pacientes com gastroparesia (GP, $n=20$ ) e outro constituído de diabéticos sem qualquer queixa de neuropatia autonômica (DC, $n=20$ ), pareados por idade e duração do diabetes. Eles foram avaliados clinicamente e submetidos a bateria de cinco testes autonômicos. A presença e a seriedade da neuropatia foi definida de acordo com os testes cardiovasculares anormais. Cada teste teve escore: zero(normal), um (limítrofe) e dois (anormal). O grupo GP teve maior escore total de testes cardiovasculares autonômicos do que o grupo DC $(6,6 \pm 3,0$ versus $2,7 \pm 1,7$, $p<0,01)$. Estes dados sugerem que diabéticos com gastroparesia apresentam maior número de testes cardiovasculares anormais do que o grupo controle e estes testes devem ser incluidos na avaliação diagnóstica do paciente diabético com gastroparesia.

PALAVRAS-CHAVE: gastroparesia, neuropatia autonômica, teste cardiovascular autonômico, neuropatia diabética.

Gastroparesis is a complication of diabetic autonomic neuropathy more frequent in longstanding insulin dependence that has been under poor control for many years, and is usually associated with other chronic microvascular complications, such as peripheral neuropathy, nephropathy and retinopathy. It has also been described in patients with early diabetes or patients in whom diabetes has been under good control $^{7}$ as well as in diabetic without autonomic neuropathy ${ }^{16}$. Clinically it manifests as nausea, vomiting, pos-prandial abdominal fullness, early satiety and abdominal pain. The diagnosis is made by delayed gastric emptying as demonstrated by sequencial imaging or tube studies with barium or tecnetium. Impaired vagal innervation due to autonomic neuropathy may

* Serviço de Endocrinologia do Hospital Universitario Prof. Edgard Santos da Faculdade de Medicina da Universidade Federal da Bahia (UFBA); ** Department of Neurology, New England Deaconess Hospital, Harvard University, Boston, Massachussetts, USA. Aceite: 13-janeiro-1997. 
lead to gastric motor dysfunction. A positive correlation between abnormal cardiovascular autonomic tests and this dystunction have been reported by some authors based on small numbers of tests of small sample size ${ }^{3.11 .14}$. Other authors have found no correlation ${ }^{2.4 .4 .18}$. Patients with cardiovascular autonomic tests abnormal have a poor prognosis and increased mortality by renal failure and sudden death'.

In this paper, we analyzed these tests results in a group of diabetic patients with gastroparesis compared to diabetic patients without any complaints of autonomic neuropathy.

\section{SUBJECTS AND METHODS}

We have studied 40 patients retrospectively: one group of diabetic subjects with gastroparesis (GP, $\mathrm{n}=$ 20), paired by age and duration of diabetes with a group of diabetic patients without any complaint related autonomous nervous system function (DC, $n=20$ ), that were referred to the New England Deaconess Hospital for autonomic cvaluation. Thirty eight of them were taking insulin, one of GP group was on glibenclamide and one of DC group was without any medication for diabetes control.

The diagnosis of gastroparesis was made in five patients by gastric emptying time of barium contrast, and in ten others was assessed by sequential scintiscanning with isotopic tecnetium*) sulfur coloid. Five of these patients were diagnosed out of New England Deaconess Hospital by gastric emptying time of barium in four and tecnetium in one.

A questionaire was administered that elicited information about symptorns of autonomic neuropathy. In the group of diabetic patients with gastroparesis, nine of them had only gastrointestinal symptoms. Seven patients had also symptomatic postural hypotension and one neurogenic bladdler. The group of diabetic patients control had no complaints compatible with gastoparesis. Thirtecn patients of GP group were taking metoclopramide, six were on fluorhydrocortisone and five on medications for hypertension (enalapril in one, captopril in two, clonidine in one and nifedipine in one). In the DC group, two patients were on nifedipine and two in enalapril. In the GP group seven patients had creatinine levels higher than $1,5 \mathrm{ng} \%$ and two others had proteinuria while in the DC group no one had increase of creatinine levels or proteinuria.

All cardiovascular autonomic tests were performed in the Autonomic Evaluation Laboratory. The patient heart rate and blood pressure measurements were obtained using the Critikon Dinamap Vital signs, monitor 1846 SX, connected to a micro-computer, which analyzed the data. The battery of cardiovascular autonomic tests used included : 1) heart rate response to deep breathing at a frequency of six breaths/min (maximum maximum heart ratc oberved in the eletrocardiogram $)^{\text {f.17}}$; 2) heat rate response to the Valsalvil maneuver for a duration of $15 \mathrm{sec}$ (n) with the determination of the ratio between the longest to the shortest heart rate interval observed in the eletrocardiogram ${ }^{12}$; 3) heart rate response to standing up (ratio between 30:1 5 beat after standing up $)^{5}$; 4) blood pressure decrease response to standing up for one minute ${ }^{1,6}$; 5) blood pressure increase response to isometric excrcise with a handgrip dinamometer for three minutes ${ }^{10}$. Each test received a score zero, if normal; one, if borderline; and two, if abnormal. The normal references values of Ewing et al. were applicel".

Statisfical analysis. This was perfomed using Epiinfo, version 5.0, data analysis program. Student's t test was applied for analysis of dati normally distributed and analysis of variance (Mann-Whitney and KruskalWallis tests) for data not normally distributed. The differences were considered significant if $\mathrm{p} \leq 0.05$.

\section{RESULTS}

The groups were similar with respect to age, duration of diabetes and degree of glycaemic control evaluated by glycosylated hemoglobin at the time of autonomic evaluation in 12 diabetics patients of group GP and 14 diabetic patients of group DC at the time of autonomic tests. The mean values and stardard deviation (SD) are on Table 1.

Results of cardiovascular autonomic tests are shown in Table 2.

The heart rate variation during deep breathing and the Valsalva ratio was smaller in the GP than in the DC group.

Blood pressure response to the isometric exercise test (hand grip) was similar in the two groups. The systolic blood pressure fall in the standing up test was higher in the GP group than the DC group ( $p<0.05)$. 
Table 1. Main characteristics of diabetic patients.

\begin{tabular}{lcccc}
\hline Group & $\begin{array}{c}\text { Sex ratio } \\
(\mathrm{m} / \mathrm{f})\end{array}$ & $\begin{array}{c}\text { Age } \\
(\text { years })\end{array}$ & $\begin{array}{c}\text { Duration of DM } \\
\text { (years) }\end{array}$ & $\begin{array}{c}\text { HbAlc* } \\
(\%)\end{array}$ \\
\hline Gastroparesis (GP) & $6 / 14$ & $34.0 \pm 13.3$ & $15.0 \pm 7.2$ & $11.1 \pm 2.9$ \\
(ranging values) & & $16-55$ & $0.5-29$ & $7.1-15.1$ \\
Dinbctic control (DC) & $9 / 11$ & $34.4 \pm 14.4$ & $15.1 \pm 7.2$ & $9.6 \pm 1.8$ \\
(ranging values) & & $21-59$ & $3-29$ & $7.3-12.4$ \\
\hline
\end{tabular}

Dilli ire me:ans $\pm S D ;{ }^{*} H b A I$ c, glycosylated hemoglobin.

Table 2. Results of cardiovascular autonomic tests in diabefic patients.

\begin{tabular}{|c|c|c|c|c|c|c|}
\hline Group & $\begin{array}{c}\text { Deep breath } \\
\text { R/R } * *\end{array}$ & $\begin{array}{c}\text { Valsalva ratio } \\
\text { R/R** }\end{array}$ & $\begin{array}{c}\text { Hand grip } \\
\uparrow \text { PA (mmHg) }\end{array}$ & $\begin{array}{l}\text { Standing up } \\
\downarrow \text { PA (mmHg) }\end{array}$ & $\begin{array}{c}30: 15 \text { ratio } \\
R^{2} / R^{* * * 1}\end{array}$ & Total score \\
\hline \multirow[t]{2}{*}{ GP } & $1.13^{*}$ & $1.24^{*}$ & 7.35 & $-36.0 \dagger$ & 1.03 & 6.61 \\
\hline & \pm 0.21 & 0.32 & 6.14 & 27.4 & 0.16 & 3.0 \\
\hline \multirow[t]{2}{*}{$\mathrm{DC}$} & 1.33 & 1.48 & 8.10 & -6.35 & 1.13 & 2.7 \\
\hline & \pm 0.22 & 0.25 & 10.70 & 8.10 & 0.21 & 1.4 \\
\hline
\end{tabular}

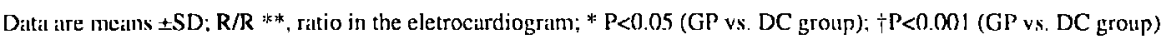

The 30:15 ratio after standing up was smaller in the GP group but this difference was not significant ( $p>0.05$ ).

The total score of all five tests was higher in the GP than in the DC group.

\section{DISCUSSION}

The results of this study indicated that cardiovascular autonomic tests in a group of diabetic patients with gastroparesis had a higher scorc of abnormalitics than that of diabetic subjetcs control.

Some authors have argued that heart rate response tests are more indicative of parasympathetic integrity, while blood pressure test would be abnormal with more cxtensive sympathetic lesion. Other authors argue that both parasympathetic and sympathetic innervation are involved in all cardiovascular autonomic tests ${ }^{\text {in }}$. In our study, the isometric exercise with a hand grip was unable to distinguish the two groups of diabetic patients. It would be possible that this test is not very sensitive or specific to autonomic damage.

Keshavarzian et al." showed that solid emptying measured by scintiscanning technique was more prolonged in diabetic with peripheral and autonomic neuropathy than diabetic with only peripheral neuropathy or diabetic without neuropatthy. They found a significant correlation between the half time of gastric emptying solid and the severity of neuropathy. Six of cight of their diabetic with gastroparesis had autonomic ncuropathy but they did not mention which or how much of these autonomic tests were abnormal. Others studies of diabetic patients with autonomic neuropathy have demonstrated that they have impaired gastric emptying compared to diabetic patients without autonomic ncuropathy ${ }^{2.3 .1 \times}$. However, Clouse \& Lustman ${ }^{4}$ suggested that gastrointestinal symptoms are more closely associated with psychiatric illness than to neuropathy. Absencc of any corrclation between abnormal autonomic tests and gastric emptying is described by some studies 2.14 . For these authors in the diabetic autonomic ncuropathy syndrome, gastric and cardiac systems are alfected 
independently. This discordance could be explained by differences in the diabetic population or even in the methodology employed to assess gastric emptying and autonomic neuropathy. Another possibility is that autonomic neuropathy in its earlier stage may show selective involvement as described Soler at al ${ }^{16}$ in one diabetic patient with gastroparesis who had normal cardiac response to the Valsalva maneuver and to the change of posture. Other causes of gastroparesis should also be considered in the differential diagnosis ${ }^{13}$.

Diabetic patients with gastroparesis have a poor diabetic control bccausc of imprcdictable oral intake and poor absortion of nutrients as a result of delayed gastric emptying. High blood glucose levels may disturb gastrointestinal motility ${ }^{8.15}$. In a recent paper, Samsum at al. ${ }^{15}$ studied antroduodenal motility in 12 insulin-dependent diabetic patients with autonomic neuropathy compared to 12 healthy control subjectcs. The blood glucose levels was controlled and kept close to euglycemia in diabetic patients. They found antral hypomotility after dinner but no difference was shown after breakfast. So besides blood glucose level, diet composition also may have influence on gastric motility. In our patients, the groups had similar diabetic control $(p>0.05)$ but we can not discharge that some gastric abnormatilies detected would be caused by abnormal high glucose levels besides autonomic neuropathy.

In conclusion, we suggest that a battery of cardiovascular autonomic tests should be included in the evaluation of diabctics with gastroparesis. It could be useful in the differential diagnosis of other causes of gastroparesis.

\section{REFERENCES}

1. Bennett T, Hosking DJ, Hampton JR. Cirdiovascular control in diabetes mellitus. Br Med J 1975,2:585-587.

2. Buysschiert M, Moulart M, Urbain JL, Pauwels S, de Roy L, Ketelslegens JM, Lambert AE. Impaired gastric emptying in diabetic patients wil cirdiac automonic neuropathy. Diubetes Care 1987;10:448-452.

3. Campbell IW, Heading RC. Tothil] P, Buist TAS, Ewing DJ, Clark BF. Gastric emptying in diabetic autonomic neuropathy. Gut 1977:18:81-86.

4. Clouse RE, Lustmun P.I. Gastric intestinal symptoms in diabetic patients: lack of association with neuropathy. Am J Gastroent 1989;84:866-872.

5. Ewing DJ, Campbel] IW, Murray A. Nelson JMM, Clarke BF. Immediate heart rate response to standing: simple test for altonomic neuropathy in diabetes. Diabetologia 1980;19:433-481.

6. Ewing DJ, Martin CN, Young RJ, Clarke BF. The value of cardiovascular autonomic function tests: 10 years experience in diabeles. Dinbetes Care 1985;8:491-498.

7. Feldmin $M \&$ Schiller LR. Disorders of gastrointestinal motility associated with diabetes mellitus. Ann Intern Med 1983;98:378-384.

8. Fraser RJ, Horowitz M, Maddox A F. Harding PE, Chatterton BE, Dent J. Hyperglycemiia slows gistric enuptying in type I (insulin-dependent) diabetes mellitus. Diabetologia 1990;33:675-680.

9. Horowizz M, Harding PE, Maddox AF, Wishart JM, Akkermans LMA, Chatterton BE, Shearmatn DJC. Gastric and oesophageal emptying in patients with Type 2 ( non-insulin-dependent) diabetes mellitus. Diabetologia 1989:32:151-159.

10. Hume L, Ewing DJ. Campbell W. Heart rate response to sustained handgrip. Clin Sci 1979:56:287-291.

11. Keshavarzian A. Jber FL. Vath J. Gastric emptying in patients with instulin-requiring diabetes mellitus. Am J Gastroent 1987:82:29-35.

12. Levin AB. A simple test of cardiac function based upon the heart rate changes induced by the Valsalva maneuver. Am J Cardiol 1966:18:901-998.

13. Oh JJ, $\mathrm{Kim} \mathrm{CH}$. Gastroparesis after a presumed viral illness: clinical ind laboratory features and natural history. Mayo Clin Proc 1990;65:636-642.

14. Pozzi M, Rivolta M, Gelosé M, Capra M, Poggiolo G, Bernasconi A, Lomuscio G. Upper gastrointestinal involvement in diabetes mellitus: study of esophago-gastric function. Acta Diabetol Lat 1988;25:333-340.

15. Samson M, Jebbink RJA, Akkermans LMA, van Berge-Henegouwen GP, Smout JPM. Abnormalities of antroduodenal motility in type 1 diabetes. Diabetes Care 1996:19:21-27

16. Soler NG \& Illinois S. Diabetic gastroparesis without autonomic neuropathy. Diabetes Care 1980;3:200-29I.

17. Sundkvist G. Almer LO. Lilja B. Respiratory influence of the heart rate in diabetes mellitus. Br Med J 1979;1:924-925.

18. Wright RA, Clemente R, Wathen R. Diabetic gastroparesis: an abnormality of gastric emptying of solids. Am J Med Sci $1985 ; 289: 240-242$. 